\title{
PEMBANGUNAN PEREKONOMIAN MASYARAKAT DESA PESISIR SEBAGAI UPAYA PENINGKATAN KESEJAHTERAAN
}

\section{ECONOMIC DEVELOPMENT OF COASTAL VILLAGE COMMUNITIES AS INCREASE WELFARE EFFORTS}

\author{
Rukin'1a \\ 1Universitas Teknologi Surabaya \\ Jl. Balong Praja V No 1, Balongsari Kec Tandes, Kota SBY, Jawa Timur 60188. \\ a Korespondensi:Rukin, E-mail: rukin.doktor@gmail.com \\ (Diterima: 20-09-2019; Ditelaah: 21-09-2019; Disetujui: 27-02-2020)
}

\begin{abstract}
This research is conducted since the development in coastal areas is still low, particularly the economic development. Due to this condition, this research aims to determine the low economy of coastal village communities, although coastal natural resources are very abundant. The government has issued public policies related to economic empowerment and the management of coastal areas. Nevertheless, the economy of coastal villages is still very low. By using qualitative methods and phenomenological approaches, findings are found about the low economy of these coastal villages. The reason for this low economy is the public is unable to capture the existing business opportunities. Also, the lifestyle of the people who are not right for generations has also been a trigger for their low economy. Lack of clear empowerment from the government to improve its economy. From the qualitative analysis, the respondents in this study were divided into three groups: community groups who work as farmers and fishermen, community groups who work as crackers, and community groups who work as farmers. The natural resources of the coastal area have not been maximally empowered by coastal communities and the lack of village infrastructure. It is hoped that the participation of the government in the handling and empowerment of their economy is expected. One solution that can be taken is reforming public policies related to the development of coastal villages. In addition, the completion of the paving and a street lighting program is also a priority program. Coaching and empowering their economy must be done immediately. Another thing that can be done by the government is the optimization of existing religious tourism and coastal tourism.
\end{abstract}

Keywords: Economic Empowerment of Coastal Village Communities.

\begin{abstract}
ABSTRAK
Penelitian ini didasari dari fenomena masih rendahnya pembangunan yang terjadi di daerah-daerah desa pesisir utamanya pembangunan di bidang perekonomian. Untuk itu penelitian ini dilakukan guna mengetahui rendahnya perekonomian masyarakat desa pesisir padahal sumber daya alam (SDA) pesisir sangat melimpah. Pemerintah sudah mengeluarkan kebijakan publik yang berhubungan dengan pemberdayaan perekonomian serta pengelolaan wilayah pesisir. Namun demikian, yang terjadi perekonomian
\end{abstract}


masyarakat desa pesisir masih sangat rendah. Dengan menggunakan metode kualitatif dan pendekatan fenomenologi didapatkan temuan-temuan tentang rendahnya perekonomian masyarakat desa pesisir ini. Penyebab rendahnya perekonomian ini diantaranya masyarakat kurang dapat menangkap peluang bisnis yang ada. Selain itu pola hidup masyarakat yang kurang tepat secara turun temurun juga menjadi pemicu rendahnya perekonomian mereka. Dari analisa kualitatif maka responden dalam penelitian ini menjadi tiga kelompok diantaranya: kelompok masyarakat yang berprofesi sebagai petambak dan nelayan, kelompok masyarakat yang berprofesi sebagai pembuat kerupuk, dan kelompok masyarakat yang berprofesi sebagai peternak. Kurang adanya pemberdayaan yang jelas dari pemerintah guna meningkatkan perekonomian mereka. Belum diberdayakannya secara maksimal SDA wilayah pesisir ini oleh masyarakat desa pesisir serta kurangnya sarana-prasarana infrastruktur desa. Diharapkan adanya peran serta pemerintah secara konkret dalam penanganan serta pemberdayaan perekonomian mereka. Salah satu solusi yang dapat diambil adalah pembenahan kebijakan publik yang berhubungan dengan pembangunan desa pesisir. Selain itu penyelesaian program pavingisasi dan penerangan jalan juga menjadi program prioritas. Pembinaan dan pemberdayaan perekonomian mereka harus segera dilakukan. Hal lain yang dapat dilakukan oleh pemerintah adalah optimalisasi wisata religi dan wisata pantai yang ada.

Kata kunci: Masyarakat Desa Pesisir, Pemberdayaan, Perekonomian.

Rukin. (2020). Pembangunan Perekonomian Masyarakat Desa Pesisir Sebagai Upaya Peningkatan Kesejahteraan. Jurnal Sosial Humaniora, 11(1), 1-14.

\section{PENDAHULUAN}

Desa-desa pesisir dan pulau-pulau kecil merupakan realitas yang keberadaannya mencerminkan masih adanya ketimpangan dalam pelaksanaan pembangunan bila dibandingkan dengan daerah di daratan pada umumnya. Oleh karena itu, kebijakan sosial ekonomi yang berhubungan dengan masyarakat pesisir perlu ditata kembali dan diarahkan untuk kesejahteraan masyarakat Indonesia khususnya masyarakat pesisir sekaligus menjaga kelestarian sumberdaya sehingga kegiatan sosial ekonomi masyarakat pesisir dapat dipercepat dan dilakukan secara berkelanjutan.

Pengelolaan sumber daya kelautan dan perikanan membutuhkan upaya secara komprehensif, terintegrasi dan terarah kebijakan, mengingat wilayah tersebut memiliki masalah, potensi, dan karakteristik yang unik. Yang paling penting adalah menjadikan kelautan dan perikanan menjadi fokus utama sektor pembangunan, yang merupakan kebutuhan untuk mengubah paradigma pembangunan (Lasabuda 2013).

Berkaitan dengan hal tersebut diatas, ada banyak hal yang harus dilakukan guna pelaksanaan pembangunan nasional. Selain itu, dalam amanah pembangunan nasional sebagaimana yang tercantum dalam UU No. 6 Tahun 2014 tentang Desa, semestinya pembangunan desa termasuk didalamnya pembangunan desa pesisir tidak hanya pada pembangunan fisik saja, akan tetapi pembangunan ini harus secara menyeluruh baik secara fisik maupun non fisik.

Pembangunan perekonomian tidak terlepas dari pembangunan pendidikan. Pembangunan pendidikan dibutuhkan adanya partisipasi masyarakat. Partisipasi masyarakat dalam perkembangan pendidikan ini cukup tinggi. Partisipasi sosial cukup tinggi, tetapi tingkat partisipasi dalam meningkatkan ekonomi keluarga sangat rendah (Saraswati 2014).

Melihat fenomena yang ada bahwa sebagian besar masyarakat desa pesisir bekerja sebagai nelayan, petambak serta buruh kasar lainnya serta masih hidup 
dalam kemiskinan. Dari kondisi seperti ini peneliti berpendapat, guna melepaskan mereka dari kondisi kemiskinan serta meningkatkan perekonomian mereka harus ada pemberdayaan perekonomian secara berkesinambungan.

Namun demikian, pemberdayaan masyarakat desa pesisir tidak terlepas dari kearifan lokal mereka secara generik. Oleh karena itu, dalam rangka pemberdayaan masyarakat desa pesisir maka pranata sosial budaya masyarakat haruslah menjadi pijakan utama. Pembangunan dan pemberdayaan masyarakat ini tidak akan bisa diterima oleh masyarakat desa pesisir dengan baik bilamana tidak pernah memperhatikan aspek-aspek sosial budaya masyarakat setempat.

Selain itu partisipasi masyarakat sangat dibutuhkan dalam pemberdayaan ini. Sebagaimana yang diungkapkan oleh (Masdjoeki, 2012), menjelaskan bahwa partisipasi merupakan pendekatan yang melibatkan masyarakat lokal dan pemerintah dalam pengelolaan sumber daya alam demikian bahwa upaya dapat dilakukan untuk meningkatkan kesejahteraan masyarakat dengan memperluas kesempatan kerja di Indonesia. Selain pengelolaan sumber daya laut berdasarkan penggunaan sumber daya yang optimal dan berkelanjutan.

Kesejahteraan (welfare) merupakan amanat undang-undang dasar 1945. Kesejahteraan pada hakikatnya merupakan tanggung jawab pemerintah. Tetapi saat ini pemerintah belum mampu secara merata untuk mensejahterakan rakyat. Hal ini dikarenakan banyaknya permasalah dalam kondisi perekonomian bangsa pasca reformasi 1998 sampai saat ini.

Tetapi sebenarnya pemerintah sampai berupaya dengan berbagai bentuk untuk mengurangi tingkat kemiskinan. Hal ini demi meningkatkan kesejahteraan bangsa walaupun hasilnya masih belum sempurna. Oleh karena itu perekonomian disusun sebagai usaha bersama berdasar atas azas kekeluargaan. Sementara itu, perekonomian dibangun berdasar atas demokrasi ekonomi demi kemakmuran bagi semua orang.

Dalam mendukung perbaikan ekonomi membutuhkan lembaga independen seperti koperasi. Tugas utama koperasi menyediakan barang dan jasa untuk memenuhi kebutuhan anggotanya. Dari lembaga ini, para nelayan memutuskan untuk bergabung dengan koperasi tersebut. (Indarti \& Wardana 2013).

Sebagai salah satu program perbaikan ekonomi ini dalam melalui program pemberdayaan ekonomi masyarakat. Sebagaimana yang diungkapkan (Miraza, 2009), menjelaskan bahwa Program Pemberdayaan Ekonomi Masyarakat Pesisir membuka peluang bagi masyarakat pesisir untuk mendapatkan fasilitas dan akses permodalan. Sementara itu, untuk pengembangan perekonomian mereka juga dapat melalui pertanian. Pengembangan pertanian pedesaan, diperlukan pendekatan untuk membantu penyuluhan pertanian yang lebih baik dan lembaga layanan pembangunan pedesaan lainnya untuk memenuhi kebutuhan dan tuntutan masyarakat setempat (Agossou, 2000).

Adanya prioritas dalam pengembangan perekonomian ini (Apriliani, 2014), menjelaskan bahwa prioritas dari semua program alternatif dalam mewujudkan Blue Economy adalah program pemberdayaan masyarakat di Indonesia memantau dan mengendalikan sumber daya laut. Saran yang bisa disampaikan upaya untuk bertransaksi dengan Blue Economy adalah panduan kelompok ekonomi masyarakat pesisir. Melihat fenomena yang terjadi diatas, perlu dilakukan pengkajian secara mendalam tentang permasalahan : "Rendahnya perekonomian masyarakat desa pesisir manakala sumber daya alam wilayah pesisir sangatlah melimpah". Perekonomian dan kemiskinan merupakan dua mata rantai yang selalu berhubungan. Rendahnya tingkat perekonomian suatu masyarakat mengakibatkan tingginya tingkat kemiskinan mereka. Oleh karena itu 
dibutuhkan kerja keras secara berkesinambungan dalam mengatasinya. Kerjasama ini hendaknya dilakukan oleh pemerintah, masyarakat secara luas dan bila dimungkinkan dari sektor swasta pun diharapkan bisa bersinergi dalam hal ini.

Namun demikian permasalahan kemiskinan memang tidak dapat teratasi dengan mudah, karena kemiskinan merupakan persoalan multidimensi yang mencakup berbagai aspek kehidupan, tidak hanya mencakup sisi ekonomi, tetapi juga sisi sosial dan budaya.

Jumlah penduduk miskin pedesaan disebabkan oleh kurangnya infrastruktur yang mendukung, serta masalah keterbatasan akses penduduk terhadap sarana dan prasarana transportasi, kesehatan, dan pendidikan. Kondisi geografis sangat mempengaruhi tingkat perekonomian mereka.

Sara (2014), menjelaskan bahwa dalam perumusan, perencanaan dan pengelolaan kawasan pesisir terpadu mencakup pengelolaan pesisir dan sumber daya dan layanan lingkungan laut hendaknya dilakukan secara komprehensif, memiliki rencana dan tujuan, kemudian merencanakan dan mengelola serta pemanfaatan semua kegiatan untuk mencapai hasil yang optimal dar berkelanjutan.

\section{Kemiskinan}

Kemiskinan dapat diartikan sebagai keadaan dimana terjadi ketidakmampuan untuk memenuhi kebutuhan dasar seperti makanan, pakaian, tempat berlindung, dan air minum. Hal tersebut sangat berhubungan erat dengan kualitas hidup. Bappenas (2004) mendefinisikan kemiskinan sebagai kondisi dimana seseorang atau sekelompok orang, laki-laki dan perempuan, tidak mampu memenuhi hak-hak dasarnya untuk mempertahankan dan mengembangkan kehidupan yang bermartabat. Hak-hak dasar masyarakat desa antara lain, terpenuhinya kebutuhan pangan, kesehatan, pendidikan, pekerjaan, perumahan, air bersih, pertanahan, sumberdaya alam dan lingkungan hidup, rasa aman dari perlakukan atau ancaman tindak kekerasan dan hak untuk berpartisipasi dalam kehidupan sosialpolitik, baik bagi perempuan maupun lakilaki.

Menurut (Chambers, 1998) kemiskinan adalah suatu integrated concept yang memiliki lima dimensi, yaitu: Kemiskinan (proper), Ketidakberdayaan (powerless), Kerentanan menghadapi situasi darurat (state of emergency), Ketergantungan (dependence), dan Keterasingan (isolation) baik secara geografis maupun sosiologis.

\section{Lingkaran Setan Kemiskinan}

Gambar 1. Lingkaran Setan Kemiskinan

Ketidakmampuan Pasar,

Keterbelakangan/

Market imperfections,

Economic backwardness

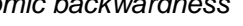

Kekurangan Modal/ Low capital
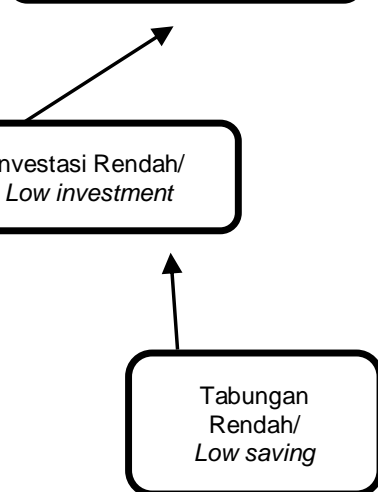

Pendapatan Rendah/ Low income

\section{Kemiskinan Masyarakat Nelayan}

Bila diperhatikan secara jelas sebenarnya banyak faktor yang menyebabkan kemiskinan masyarakat nelayan, selain faktor internal juga adanya faktor eksternal. Menurut (Kusnadi, 2003), membedakan faktor penyebab kemiskinan nelayan dalam dua kelompok yaitu kemiskinan nelayan secara internal dan kemiskinan nelayan secara eksternal. 
Sementara itu (Kusnadi, 2003) juga menjelaskan bahwa kemiskinan nelayan yang bersifat internal, mencakup: (1) keterbatasan kualitas sumber daya manusia nelayan; (2) keterbatasan kemampuan modal usaha dan teknologi penangkapan; (3) hubungan kerja dalam organisasi penangkapan yang seringkali kurang menguntungkan buruh; (4) kesulitan melakukan diversifikasi usaha penangkapan; (5) ketergantungan yang tinggi terhadap okupasi melaut; dan (6) gaya hidup yang dipandang boros, sehingga kurang berorientasi ke masa depan.

\section{Pemberdayaan Masyarakat Desa Pesisir dalam Pengentasan Kemiskinan}

Untuk menanggulangi kemiskinan di Indonesia perlu diketahui faktor apa sajakah yang mempengaruhi tinggi rendahnya tingkat kemiskinan sehingga kedepannya dapat diformulasikan sebuah kebijakan publik yang efektif untuk mengurangi tingkat kemiskinan. Selain itu juga adanya strategi dan kebijakan alternatif yang berpihak kepada rakyat miskin menjadi kebutuhan mutlak menanggulangi kemiskinan.

Selain itu strategi dan kebijakan alternatif menanggulangi kemiskinan masyarakat desa termasuk didalamnya desa pesisir dapat dilakukan dengan cara memberikan kesempatan yang luas kepada masyarakat untuk memperoleh layanan pendidikan serta pelayanan kesehatan yang memadai. Selain itu juga memperkuat komitmen eksekutif dan legislatif untuk memperbaiki tatanan pemerintahan dan mendorong agenda pembangunan daerah memprioritaskan pemberantasan kemiskinan sebagai skala prioritas yang utama. Kebijakan dan program yang memihak orang miskin perlu difokuskan kepada sektor ekonomi riil dan harus menggunakan paradigma keberpihakan kepada orang miskin.

\section{MATERI DAN METODE}

Untuk memperoleh jawaban yang jelas sesuai yang diharapkan maka penelitian ini menggunakan metode kualitatif dan didukung dengan pendekatan fenomenologi. Pendekatan fenomenologi merupakan tradisi penelitian kualitatif yang berakar pada filosofi dan psikologi, dan berfokus pada pengalaman hidup manusia (sosiologi). Dengan metode fenomenologi inilah diharapkan nantinya mendapatkan gambaran yang kongkrit tentang pembangunan desa pesisir ini serta melihat partisipasi masyarakat dalam setiap proses pembangunan ini.

Hal ini sependapat dengan (Denzin \& Loncoln, 2009) bahwa fenomenologi secara kritis dapat diinterpretasikan secara luas sebagai sebuah gerakan filsafat secara umum memberikan pengaruh emansipatoris secara implikatif kepada metode penelitian sosial. Pengaruh tersebut di antaranya menempatkan responden sebagai subyek yang menjadi aktor sosial dalam kehidupan sehari-hari.

Sementara itu, untuk mendapatkan hasil yang akurat, dilakukan wawancara secara mendalam dengan individu yang berpengetahuan luas yang memahami tentang masalah yang sedang dipelajari. Teori yang digunakan sebagai referensi adalah teori (Merriam, 2002).

Dari analisa kualitatif maka responden dalam penelitian ini menjadi tiga kelompok diantaranya: kelompok masyarakat yang berprofesi sebagai petambak dan nelayan, kelompok masyarakat yang berprofesi sebagai pembuat kerupuk, dan kelompok masyarakat yang berprofesi sebagai peternak.

\section{HASIL DAN PEMBAHASAN}

Sebagai salah satu Kabupaten penopang Kota Surabaya serta memiliki kawasan industri dan pergudangan yang cukup 
banyak dan besar, Kabupaten Sidoarjo telah lama mengikrarkan diri untuk meningkatkan perekonomian masyarakat sebagai upaya mengentaskan kemiskinan diseluruh wilayah. Kemiskinan merupakan salah satu permasalahan utama dan mendesak yang harus segera dipecahkan.

Secara sinergis dan sistematis penanggulangan kemiskinan harus dilakukan agar seluruh warga negara mampu menikmati hasil-hasil pembangunan dan kehidupan yang bermartabat. Oleh karena itu, sinergitas dari seluruh pemangku kebijakan dan kepentingan (stakeholders) serta peran serta masyarakat secara luas sangatlah diperlukan.

Strategi tersebut dijalankan dengan berbagai program penanggulangan kemiskinan. Kegiatan yang dilakukan oleh pemerintah, dunia usaha, serta masyarakat untuk meningkatkan kesejahteraan masyarakat miskin melalui bantuan sosial, pemberdayaan masyarakat, pemberdayaan usaha ekonomi mikro dan kecil, serta program lain dalam rangka meningkatkan kegiatan ekonomi.

Namun demikian dalam pelaksanaan program itu pun sepertinya pemerintah belum mengikutsertakan partisipasi masyarakat secara luas agar segala program yang dilakukan oleh pemerintah ini tepat sasaran dan sesuai dengan yang diinginkan. Oleh karena itu ke depan hendaknya pemerintah mengikutsertakan partisipasi masyarakat secara luas. Selain program yang dilakukan bisa tepat sasaran, dengan peran serta masyarakat diharapkan bisa menjadi kontrol dalam pelaksanaan program tersebut.

Dari hasil penelitian yang didapatkan dari wawancara secara mendalam kepada para informan ditemukan bahwa kondisi perekonomian masyarakat desa pesisir ini masih berada dibawah garis kemiskinan. Sedangkan bila dilihat dari kondisi yang ada, sumber daya alam wilayah pesisir masih sangat melimpah. Hal ini dikarenakan kurang adanya pemberdayaan kepada masyarakat desa pesisir ini secara maksimal. Untuk meningkatkan tingkat perekonomian masyarakat desa pesisir ini dibutuhkan kepedulian dari seluruh komponen pemangku kebijakan dan pihak swasta.

Sementara itu guna mempercepat pembangunan di Kabupaten Sidoarjo sebagai upaya peningkatan perekonomian masyarakat utamanya masyarakat desa pesisir maka pada tahun 2013 pemerintah Kabupaten Sidoarjo telah mengeluarkan Peraturan Bupati Sidoarjo Nomor 57/2013 Tentang Rencana Rinci Masterplan Kawasan Strategis Pesisir Kabupaten Sidorjo Indonesia. Walaupun peraturan Bupati tersebut telah dijelaskan secara gamblang dan terperinci dimana wilayah pesisir dengan sumber daya alamnya memiliki arti penting bagi pembangunan ekonomi dan ekosistem, karena kawasan pesisir merupakan kawasan sumber hayati dan non hayati yang sangat produktif. Namun demikian pengimplementasian kebijakan tersebut belum dilaksanakan sesuai dengan harapan masyarakat desa pesisir.

Dari pengamatan di lapangan, wilayah pesisir Sidoarjo Indonesia ini ternyata memiliki peluang yang sangat besar dalam mengembangkan pariwisata bahari maupun pariwisata pesisir serta pariwisata religi. Wilayah pesisir yang dimiliki oleh Sidoarjo dan sangat luas dan indah. Terdapat keindahan Pantai Kepetingan dan Teluk Permisan yang ada di sepanjang pantai Sidoarjo ini. Rukin, 2015 menjelaskan bahwa Makam Dewi Sekardadu yang letaknya sangat berhimpitan serta memiliki pesona dan panorama alam yang sangat indah. Bila kondisi ini diberdayakan secara maksimal maka akan membuka peluang usaha bagi masyarakat desa pesisir ini.

Oleh karena itu ke depan hendaknya benar-benar terlaksana secara benar agar area wisata ini bisa maju guna meningkatkan perekonomian masyarakat desa pesisir. Bila dikembangkan secara maksimal akan adanya pemasukan baru 
bagi pemerintah serta membuka lapangan pekerjaan bagi masyarakat sekitar utamanya masyarakat di daerah desa pesisir ini. Oleh karenanya dibutuhkan keseriusan secara bersama-sama antara pemerintah dan masyarakat lokal serta pihak lain dalam pengelolaan pariwisata ini.

Namun demikian pada sektor pariwisata pesisir inilah yang sebenarnya kurang adanya pengelolaan secara maksimal. Padahal bila ini benar-benar dikelola dengan baik maka hasilnya akan dirasakan secara umum oleh masyarakat, khususnya bagi masyarakat desa pesisir di wilayah Kabupaten Sidoarjo Indonesia. Dengan pengelolaan pariwisata ini akan terbukanya lapangan kerja baru bagi masyarakat.

Menghadapi permasalahan itu akhirnya masyarakat desa pesisir ini mencoba membuat usaha lain. Seperti beternak ikan dan udang dengan media terpal ataupun membuat kerupuk ikan dan kerupuk udang dan kesemuanya itu dilakukan dengan modal seadanya. Selain itu juga ada sebagian kecil masyarakat yang membuka warung pracangan serta warung makan maupun sejenisnya dengan modal yang sangat pas pasan. Semua itu dilakukan guna memenuhi kebutuhan mereka dan keluarganya.

Walaupun kenyataannya dalam berbelanja pun masyarakat sering pinjam atau dalam istilah lain "gali lobang tutup lobang". Dari hal inilah nampaklah jelas adanya budaya yang kurang bagus terjadi secara berkelanjutan. Dikarenakan budaya ini akan menjadikan mereka semakin terbelenggu dalam kemiskinan yang berkepanjangan. Penghasilan yang mereka dapatkan selalu tidak menentu, akan tetapi sistem menghutang selalu mereka lakukan. Besar kemungkinan nantinya akan terjadinya eksploitasi terhadap anak-anak mereka, Rukin,2018.

Namun demikian tidak semua masyarakat desa ini hanya mengandalkan bantuan dari pemerintah. Sebagai salah satu contoh usaha baru yang dilakukan oleh sebagian masyarakat dengan membuat kolam ikan dari terpal di depan rumahnya. Hal ini dilakukan karena tingkat penghasilan tambak mereka yang tidak menentu.

Dengan mengandalkan hasil tangkapan ikan di laut maupun di sepanjang sungai Kepetingan sering merosotnya. Ditambah lagi tingginya pengeluaran bahan bakar maupun biaya pembelian solar maupun bensin yang dipergunakan untuk mencari ikan dengan menggunakan perahu, sedangkan hasil ikan sering merosot.

Oleh karena itu, menjadikannya harus berinovasi dengan usaha lain agar bisa mencukupi kebutuhan hidup keluarganya. Untuk memenuhi kebutuhan ini maka sebagian masyarakat membuat kolam ikan semi permanen dari terpal di halaman depan rumah mereka. Kolam-kolam itu untuk memelihara ikan lele dan udang dengan harapan hasilnya bisa dipergunakan untuk menopang perekonomian mereka.

Sementara itu dari pengamatan di lapangan memang masyarakat desa ini belum bisa membuka peluang usaha baru dari hasil laut maupun tambak baik itu ikan maupun udang kecuali hanya membuat kerupuk yang masih kurang maksimal. Ini semua sebenarnya disebabkan karena kurang pengetahuan mereka dan kurang adanya pembinaan dari pemerintah.

Diperlukan adanya pembinaan guna meningkatkan perekonomian mereka. Baik itu dilakukan oleh pemerintah atau dari swasta yang memiliki keinginan bersama untuk meningkatkan perekonomian masyarakat desa pesisir ini. Ternyata peran serta pemerintah dalam pembinaan kewirausahaan kepada masyarakat desa pesisir ini masih kurang. Hal ini terjadi karena faktor geografis yang sangatlah sulit untuk dijangkau.

Dari berbagai permasalahan diatas nampak jelas bahwa pemerintah masih kurang dalam melakukan pemberdayaan kepada masyarakat. Utamanya terhadap usaha-usaha mereka agar mendapatkan hasil yang maksimal guna meningkatkan 
perekonomian mereka. Sementara itu pemerintah juga kurang memberikan wawasan kepada masyarakat dalam hal pemasaran terhadap usaha rumahan yang dilakukan oleh masyarakat desa pesisir.

Rendahnya tingkat perekonomian mereka dikarenakan kurang adanya pembinaan kewirausahaan dari pemerintah. Ternyata pemerintah hanya memberikan bantuan dana berupa bantuan Program Keluarga Harapan (PKH) tanpa ada pembinaan kewirausahaan. Sebenarnya bantuan itu dipergunakan untuk membuat usaha yang tentunya dapat meningkatkan perekonomian mereka.

Adanya kesalahan sebuah sistem yang dilakukan oleh pemerintah dengan hanya memberikan bantuan tanpa pernah memberikan solusi penggunaannya. Karena sudah menjadi kebiasaan masyarakat bila mendapatkan bantuan, maka pola hidup mereka akan meningkat. Daya beli mereka akan naik sesaat tanpa memikirkan kehidupan selanjutnya. Hal inilah yang menjadi kelemahan bagi masyarakat di desa pesisir ini.

Dari hasil pengamatan dilapangan rendahnya tingkat pendidikan mereka juga mempengaruhi tingkat perekonomian. Sejak dahulu masyarakat desa pesisir hanya bekerja sebagai nelayan tradisional maupun petani penggarap tambak, selalu menganggap bahwa pendidikan belum menjadi kebutuhan yang penting.

Tingkat pendidikan ternyata sebagai salah satu indikator dari kualitas Sumber Daya Manusia. Karena dari indikator tingkat pendidikan inilah yang menjadikan masyarakat itu dikatakan miskin ataupun bukan miskin. Karena kebanyakan dari mereka yang berpendidikan rendah, diyakini memiliki produktivitas yang rendah pula. Sementara itu dengan rendahnya produktivitas akan berpengaruh pada rendahnya tingkat pendapatan mereka. Rendahnya tingkat pendapatan maupun penghasilan sebagai salah satu ciri dari penduduk kurang mampu atau penduduk miskin.

Sementara itu masyarakat desa pesisir memiliki pemikiran bahwasanya pekerjaan sebagai nelayan maupun pekerja sebagai petani maupun penggarap tambak tidak memerlukan pendidikan yang tinggi-tinggi, masyarakat selalu beranggapan bahwa sebagai seorang nelayan maupun pekerja sebagai petani dan penggarap tambak merupakan pekerjaan kasar yang lebih banyak mengandalkan tenaga otot bukan otak dan pengalaman bukan pemikiran, maka setinggi apapun pendidikannya tidak akan berpengaruh bagi kemampuan mereka.

Selanjutnya akan muncul persoalan baru dari rendahnya tingkat pendidikan yang mereka peroleh, serta pendidikan anakanak mereka sangatlah rendah maka akan berpengaruh pada saat anak-anak mereka mencari pekerjaan lain yang nantinya diharapkan dapat meningkatkan pendapatan mereka sangatlah sulit.

Karena dengan tingkat pendidikan rendah yang mereka miliki atau bahkan hanya lulus SD, maka akan mempersulit mereka untuk memilih atau memperoleh pekerjaan lain selain menjadi nelayan dan pekerja di tambak. Dari sinilah dapat diyakini bahwa rendahnya pendidikan masyarakat pesisir inipun sangatlah berpengaruh terhadap tingkat perekonomian mereka. Dan akhirnya disini akan terjadinya kemiskinan yang turun temurun.

Kondisi budaya dan kebiasaan mereka juga sangat berpengaruh terhadap tingkat perekonomian mereka. Rendahnya tingkat perekonomian dan kemungkinan kemiskinan yang dialami oleh masyarakat desa pesisir ini disebabkan oleh pola hidup yang kurang tepat dari masyarakat desa pesisir itu sendiri.

Seperti fenomena hajatan masyarakat, biasanya modal hajatan yang digunakan itu pinjaman dari tetangga yang lebih mampu. Akan tetapi kenyataannya hasil yang didapatkan hanya balik maksimal 50\% dari 
biaya yang dipergunakan. Hal ini merupakan adat turun temurun dan dianggap untuk sebuah kerukunan. Fenomena di atas inilah yang menjadikan mereka semakin hidup dalam kekurangan. Sedangkan hal ini merupakan tradisi secara turun-temurun ini sulit untuk dihilangkan.

Selain berbagai macam hal diatas, banyak sekali masyarakat desa pesisir ini yang berprofesi sebagai nelayan. Akan tetapi kebiasaan yang salah pun kadang kala dilakukan oleh para nelayan. Pada saat berangkat melaut mencari ikan kadangkala dengan menggunakan biaya pinjaman dari para pengepul ikan. Harapannya hasil tangkapannya nantinya bisa dijual kepada para pengepul dengan dipotong pinjaman mereka.

Namun demikian bila nelayan itu mendapatkan hasil maka mereka akan pulang membawa uang sisa hasil tangkapannya. Akan tetapi kalau sampai tangkapan ikannya hanya sedikit dan merosot, maka dipastikan untuk menutup pinjaman nya pun menjadi kurang, dengan demikian maka hutang mereka kepada para pengepul akan semakin banyak. Oleh karena itu mereka pastinya akan semakin terjerat oleh hutang-hutang kepada para pengepul ikan ini.

Hal yang hampir sama dilakukan oleh para petani tambak penggarap. Disaat mereka memulai menggarap tambak, menebar benih ikan memberinya makanan sampai pada proses pemanenan, kadang kala mereka juga menggunakan dana pinjaman. Bilamana hasilnya cukup lumayan maka mereka akan mendapatkan hasil yang maksimal. Akan tetapi bilamana sebaliknya sudah pasti mereka akan mengalami kerugian yang banyak.

Hal inilah yang juga kurang terpikirkan oleh masyarakat ini. Melihat fenomena ini semestinya adanya upaya pembinaan ataun pemberian pinjaman modal kepada mereka untuk memulai usaha dengan sistem pengembalian yang sangat fleksibel. Bila ini bisa terjadi maka dapat dipastikan mereka tidak akan berada dalam sebuah lilitan hutang.

Sementara itu para istri mereka tidak memiliki keterampilan yang lain. Setelah dilakukan pengamatan di lapangan, ketidakmampuan mereka dikarenakan tingkat pendidikan yang rendah dan pengalaman yang minim serta kurang adanya pemberdayaan dari pemerintah tentang kewirausahaan. Padahal pembuatan makanan dari hasil olahan ini nantinya bisa dipasarkan sampai keluar desa atau bahkan keluar daerah.

Akan tetapi kenyataannya masyarakat belum bisa menangkap peluang ini. Sedang hasil dari itu semua dapat dipergunakan untuk menopang perekonomian mereka. Hal inilah yang sebenarnya memerlukan perhatian yang serius. Belum adanya kesadaran dari masyarakat ataukah hanya kemalasan mereka saja sehingga peluang ini tidak pernah ditangkap oleh mereka.

Hal ini diperlukan adanya pembinaan kewirausahaan dari pemerintah maupun pihak swasta untuk menjadi pendamping mereka termasuk sampai pada proses pemasarannya. Dan bilamana memungkinkan adanya bantuan permodalan yang dapat mereka lakukan untuk memulai usaha dengan sistem pembayaran yang lebih mudah. Jika ini terjadi maka diyakini tingkat perekonomian mereka akan mengalami peningkatan.

Akan tetapi pertanggungjawaban ini semua haruslah dikelola secara berkelompok, bukanlah secara individu. Dikarenakan banyaknya kejadian di beberapa daerah sekitar bahwa uang pinjaman masyarakat ini yang bersumber dari dana pemerintah banyak yang tidak dikembalikan. Untuk menghindari hal tersebut maka sebaiknya pinjaman modal ini dilakukan secara kelompok dan penanggung jawabnya adalah ketua kelompok. Hal ini dimungkinkan kondisinya menjadi lebih aman dengan satu penanggung jawab keuangan. Karena kebiasaan yang terjadi dilapangan bahwa 
bila pinjaman itu diatas namakan secara individu maka kemungkinan mengembalikan pinjaman tersebut sangatlah sulit.

Sementara itu selain berbagai permasalahan diatas, masih ada hal lain yang kurang teratasi di desa ini yaitu adanya peternakan kambing yang kurang adanya pembinaan dari Dinas Peternakan. Ada hampir dua ribuan kambing yang diternak di desa Sawohan ini yang dimiliki oleh sekitar 36 orang yang tergabung dalam kelompok peternak kambing "Oro-Oro". Dan kandang-kandang ini dijadikan satu tempat di tengah area pertambakan. Selain peternak yang masuk dalam kelompok "Oro-Oro", masih banyak peternak-peternak lain bersifat individu yang tidak masuk dalam kelompok ini. Banyaknya kandangkandang kambing yang berada di area pertambakan dan sekitar perkampungan masyarakat, membuktikan bahwa adanya lebih dari dua ribuan kambing yang ada di peternakan ini.

Sedangkan para pemilik peternakan kambing ini hanya mengikuti tradisi turun temurun yaitu membiarkan hewan ternaknya keluar kandang di pagi hari dan pulang di sore hari. Dengan hanya mengandalkan makan rumput dari pematang tambak dan tanpa pernah memberikannya nutrisi lain agar kambingkambing ini menjadi lebih sehat. Sementara itu biasanya pengecekan kesehatan hewan ternak tersebut biasanya dilakukan oleh Dinas Peternakan lima bulan sekali dan itu pun kalau diminta oleh kelompok peternak.

Sebenarnya para peternak ini memiliki kelompok usaha peternakan kambing, akan tetapi peternakan yang dikelola masih tradisional sekali. Kelompok ini hanyalah sebagai wadah komunikasi dan belum pada tataran pengelolaan usaha peternakan ini agar menjadi lebih baik dan lebih maju.

Jika dikelola secara baik dan modern, peternakan ini dimungkinkan akan mendapatkan hasil yang maksimal dan tentunya dapat menopang perekonomian mereka. Karena kotoran sehari saja kalau dikumpulkan hampir mencapai 2-3 kwintal. Oleh karena itu bilamana ini memang teratasi dengan baik, dimungkinkan akan menjadi sentra peternakan kambing yang lumayan besar di daerah ini.

Untuk itu sangat diperlukan upaya para peternak ini dan dibantu serta diberikan pembinaan oleh pemerintah secara maksimal untuk membuat inovasi baru dalam pengelolaan peternakan ini. Selain itu setidaknya adanya upaya bersama dalam pengelolaan peternakan ini sampai pada tataran pemasaran hasil ternak kambing ini dalam sebuah manajemen yang bagus.

Dari peternakan inilah bila dikembangkan akan membuka peluang usaha baru seperti halnya layanan hewan aqiqah dan hewan qurban. Hal ini bisa dilakukan secara berkelompok di desa ini ataukah hanya sebagai penyuplai hewan saja. Disinilah tentunya akan membuka peluang lapangan pekerjaan baru bagi masyarakat.

Selain melalui sektor industri rumah tangga, perikanan dan peternakan, di daerah ini sangatlah cocok untuk dikembangkan sektor pariwisata. Dengan menjadikan Teluk Permisan serta hutan mangrove yang ada disekitarnya dan situs makam Dewi Sekardadu menjadi tujuan wisata pantai dan wisata religi yang bagus, maka diharapkan adanya tambahan pendapatan bagi masyarakat desa pesisir ini utamanya masyarakat dusun Kepetingan Sawohan.

Dari pengamatan di lapangan, sebenarnya sudah banyak sekali masyarakat dari luar daerah yang berkunjung ke situs makam Dewi Sekardadu ini. Utamanya bila hari minggu maupun hari libur banyak sekali peziarah yang datang ketempat ini. Apalagi pada saat hari besar Islam, semisal menjelang Ramadhan, bulan Rabiul Awal, peziarahan di situs makam Dewi Sekardadu ini semakin banyak. Namun demikian sampai saat ini kedua objek wisata ini 
belum dikelola dengan baik, bahkan hutang mangrove nya pun kurang begitu terurus.

\section{Pemberdayaan \\ Perekonomian Masyarakat Desa Pesisir}

Dari berbagai temuan di atas, sebenarnya pemerintah sudah memberikan bantuan kepada masyarakat desa pesisir ini guna meningkatkan kesejahteraan mereka. Akan tetapi sepertinya belum tepat pada sasaran yang diinginkan. Sedangkan inti permasalahan yang dihadapi oleh masyarakat utamanya para pembuat kerupuk, yaitu kurang adanya peran pemerintah yang tepat dalam rangka meningkatkan perekonomian mereka. Karena sebenarnya bukan hanya pinjaman modal lunak saja yang diharapkan, akan tetapi pada tataran pembinaannya harus dilakukan secara maksimal.

Selain itu masyarakat kurang dapat menangkap peluang usaha baru dari hasil ikan maupun udang ini. Sebenarnya ikan yang kurang laku dipasaran bisa mereka olah menjadi bentuk lain yang nantinya lebih mudah untuk menjualnya dan tentunya harganya pun bisa lebih mahal. Akan tetapi harus adanya pembinaan utamanya dari Dinas Ketahanan Pangan dan Dinas Koperasi UMKM serta BPMPKB. Termasuk pembinaan dari Dinas Perindustrian dan Perdagangan memberikan pembinaan kepada usaha rumahan ini. Intinya memberikan pemahaman kepada masyarakat dalam pembuatan makanan olahan hasil laut dan tambak seperti halnya pentol ikan, pentol udang, tempura, serta makanan lainnya yang layak jual dan tidak hanya fokus pada pembuatan kerupuk saja.

Dibutuhkan peran serta pemerintah untuk memberikan pembinaan kepada masyarakat untuk membuka peluang usaha baru dari komoditi wilayah pesisir. Usaha-usaha ini diantaranya pembuatan pentol dari ikan laut maupun udang, serta pengeringan ikan yang terbina oleh Dinas Ketahanan Pangan dengan harapan hasilnya bisa menembus pasar-pasar modern. Agar menjadi usaha yang sedikit modern maka dibutuhkan sistem pengelolaan dan pemasaran yang baik, maka diharapkan desa bisa mengelola usaha ini dalam sebuah Badan Usaha Milik Desa (BUMDes) yang berfungsi menampung dan menjual hasil usaha ini.

Berkaitan dengan usaha yang sudah dirintis oleh masyarakat berupa pembuatan kerupuk dan terasi yang pemasarannya belum maksimal, BUMDes bisa melakukan terobosan-terobosan baru agar pemasarannya menjadi lebih bagus. Dengan mengadakan kerjasama bersama supermarket-supermarket dan pasar swalayan yang ada. Pemasaran yang bagus dimungkinkan produksinya akan semakin meningkat. Dengan demikian diyakini adanya penambahan pekerja yang tentunya juga berasal dari masyarakat desa setempat.

Semakin berkembangnya usaha yang dikelola oleh masyarakat nantinya BUMDes ini bisa menjadi lebih besar. Hal ini dikarenakan adanya pemasukan persentase dari setiap penjualan yang terjadi yang masuk ke kas BUMDes. Semakin berkembangnya usaha yang dikelola ini diharapkan desa tersebut akan menjadi desa Swasembada dan juga menjadi desa Sentra Industri olahan Hasil Laut. Tidak hanya memproduksi kerupuk dan terasi tetapi juga memproduksi ikan kering yang berdaya saing tinggi.

Hal ini akan terjadi dengan adanya pembinaan dari pemerintah serta kepedulian para pemangku kebijakan dan partisipasi aktif dari seluruh lapisan masyarakat lokal. Selain itu diharapkan adanya bantuan dari pihak swasta yang peduli terhadap perekonomian masyarakat desa pesisir.Ini merupakan modal dasar bagi masyarakat desa pesisir ini untuk mengembangkan usahanya menjadi lebih besar.

Berkaitan dengan permasalahan industri rumahan dan sektor perikanan, para peternak kambing pun perlu dilakukan pemberdayaan dengan jalan adanya 
pembinaan yang lebih intens dari Dinas Peternakan dan Kesehatan Hewan. Serta pemerintah memberikan bantuan berupa kambing pejantan besar sebagai pembibit. Dengan demikian diyakini peternakan mereka pun akan menjadi besar, binatang ternaknya menjadi sehat dan hasilnya tentu akan lebih meningkat.

Sistem pemasarannya selain dilakukan sendiri-sendiri dan kelompok, juga bisa melalui BUMDes yang sudah mempunyai terobosan-terobosan keluar dalam bidang pemasaran. Termasuk membuka sentra pelayanan qurban dan aqiqoh yang dikelola langsung oleh BUMDes. Dari sinilah dipastikan akan terbukanya lapangan pekerjaan baru bagi masyarakat desa pesisir ini. Selain itu, para peternak yang belum tergabung didalam kelompok peternak yang ada hendaknya segera bergabung, agar mendapatkan pelayanan peternakan yang sama. Dengan adanya peningkatan pendapatan masyarakat desa pesisir dan perekonomian mereka membaik, maka mereka akan terlepas dari belenggu kemiskinan.

Sementara itu, melalui wisata bahari, wisata pesisir dan wisata religi diharapkan juga dapat menopang perekonomian masyarakat desa pesisir. Oleh karena itu dengan memajukan ketiganya diharapkan perekonomian masyarakat desa pesisir akan semakin meningkat. Wisata bahari dan pantai Teluk Permisan serta wisata religi situs makam Dewi Sekardadu diharapkan menjadi tujuan wisata masyarakat secara luas.

Dengan perbaikan dan penyelesaian pavingisasi serta pemberian lampu penerangan yang ada di tengah-tengah area pertambakan akan memperlancar perjalanan menggunakan sepeda motor. Bagi rombongan wisatawan dan peziarah yang menggunakan bus maupun mobil pribadi bisa memarkirkan kendaraannya di tempat parkir masyarakat. Selanjutnya naik ojek menuju obyek wisata tersebut sambil menikmati indahnya area pertambakan. Dengan demikian adanya usaha baru yang dilakukan masyarakat desa pesisir dengan menjadi tukang parkir dan tukang ojek. Selain itu dengan membuka kios-kios yang menjajakan oleh-oleh khas masyarakat desa pesisir ini maupun menjual makanan lainnya atau hanya sekedar menjual souvenir.

Dinas Pariwisata segera melakukan pengelolaan dengan baik wisata pesisir Teluk Permisan dan wisata religi ke situs makam Dewi Sekardadu. Dengan dikelola secara baik maka dimungkinkan berimbas pada perekonomian masyarakat sekitar. Selain itu adanya pemasukan lain Pendapatan Asli Daerah (PAD) sektor Pariwisata. Pemerintah bisa menggandeng pihak swasta agar Wisata Bahari di sekitar Teluk Permisan ini segera direalisasikan. Maka akan adanya peluang usaha baru serta terbukanya lapangan pekerjaan bagi masyarakat desa pesisir. Hal ini akan terjadi dengan adanya kerjasama pemerintah maupun pihak swasta dan dukungan serta partisipasi masyarakat desa pesisir.

Untuk mempercepat proses pengelolaan pariwisata ini bisa melakukan kerjasama dengan pihak ketiga dan para investor pariwisata. Dengan terbukanya pariwisata ini maka akan terbuka pula lapangan pekerjaan baru. Dengan terbukanya lapangan kerja baru diharapkan tingkat perekonomian masyarakat desa pesisir akan meningkat. Selain itu diharapkan wawasan masyarakat desa pesisir ini akan semakin luas.

Pengelolaan pariwisata bisa dilakukan secara bersama-sama antara sektor swasta, Dinas Pariwisata Kabupaten Sidoarjo dan Pemerintah Desa. Sistem pendapatannya dengan bagi hasil sesuai dengan tugas dan tanggung jawabnya masing-masing. Hal ini agar perawatan jalan menuju area wisata ini menjadi tanggung jawab desa dari uang bagi hasil pengolahan tersebut. Dengan sistem inilah yang mungkin lebih efektif bila dibandingkan dikelola langsung oleh sektor swasta. 
Karena daerah ini sulit sekali untuk melakukan komunikasi dengan menggunakan telepon seluler. Diharapkan adanya kerjasama dengan provider yang mau dan siap untuk membuat pemancar transmisi didaerah ini. Hal ini dimungkinkan karena para wisatawan tentunya menginginkan jaringan komunikasi yang lancar. Diharapkan pemerintah menggandeng salah satu atau lebih provider untuk membuat antena pemancar di daerah ini. Karena dengan adanya komunikasi yang lancar diharapkan wisatawan akan semakin senang untuk mendatangi tempat ini.

\section{KESIMPULAN}

Dari hasil analisa diatas dapat ditarik kesimpulan bahwa rendahnya tingkat perekonomian masyarakat desa pesisir ini dikarenakan masyarakat belum memanfaatkan SDA pesisir dengan sebaikbaiknya. Selain itu masyarakat juga belum mampu menangkap peluang bisnis dari hasil pemanfaatan sumberdaya pesisir karena rendahnya tingkat pendidikan serta kurang adanya pembinaan dari pemerintah. Sementara sarana prasarana pendukung dan infrastruktur desa pesisir ini juga masih jauh dari yang diharapkan, sehingga menghambat proses pembangunan dari segala aspek.

Guna menyelesaikan berbagai permasalahan ini dibutuhkan kepedulian secara bersama-sama baik dari pemerintah maupun sektor swasta dalam memberikan pembinaan kewirausahaan kepada masyarakat desa pesisir agar segera menangkap peluang bisnis. Program pembenahan infrastruktur jalan dan penerangan menjadi prioritas utama pemerintah. Pemerintah Desa segera mendirikan BUMDes serta mencari terobosan-terobosan baru dalam sistem penjualan hasil olahan masyarakat dan peternakan. Hal ini diperuntukkan agar segala usaha olahan hasil laut yang dilakukan oleh masyarakat mudah untuk dipasarkan.

\section{DAFTAR PUSTAKA}

Agossou (2000) Village Participation in Rural Development. Royal Tropical Institute / World Bank. ISBN 906832 1366.

Apriliani (2014) Economics development analysis. Journal Universitas Negeri Semarang. ISSN 2252-6765.

Bappenes. 2014, Rencana Pembangunan Jangja Menengah Nasional (RPJMN) 20152019. Kementrian Perencanaan Pembangunan Nasional/ Badan Perencanaan Pembangunan Nasional.

Denzin and Lincoln, 2009, Handbook of Qualitative Research. Edisi Bahasa Indonesia. Pustaka Pelajar. Yogyakarta.

Indarti \& Wardana (2013) Metode pemberdayaan masyarakat pesisir melalui penguatan kelembagaan di wilayah pesisir Kota Semarang. BENEFIT Jurnal Manajemen dan Bisnis, 17 (1):7588.

Kusnadi. 2002, Konflik Sosial Nelayan, Kemiskinan dan Perebutan Sumberdaya Perikanan (Yogyakarta: LKiS, 2002).

Lasabuda (2013) Pengelolaan sumberdaya perikanan dan kelautan. Jurnal Ilmiah Platax, I-2. ISSN: 2302-3589.

Mardjoeki (2012) Pemberdayaan masyarakat pesisir pantai utara daerah Kabupaten Cirebon. Jurnal Ekonomi, 1 (1). ISSN: 2302-7169

Miraza R (2009) Implementasi Program Pemberdayaan Ekonomi Masyarakat Pesisir (PEMP) di Kecamatan Tanjung Pura Kabupaten Langkat, Universitas Sumatera Utara.

Merriam SB (2002) Introduction to Qualitative Research. JOSEY-BASS, A Wiley Company - San Fransisco.

Peraturan Bupati Sidoarjo Nomor 57 Tahun 2013 Tentang Rencana Rinci Masterplan Kawasan Strategis Pesisir Kabupaten Sidorjo. 
Rukin (2015) Pariwisata pesisir sebagai salah satu alternatif pemberdayaan perekonomian masyarakat desa pesisir. Jurnal Ilmiah Sosial \& Humaniora, 9 (1):36-46. Universitas Surabaya, 2015.

Rukin, B. Rahman, A. Toha, and N.D. Gianawati. 2018. Coastal rural community economic development as a poverty reduction efforts. The International Journal of Social Sciences and Humanities Invention, Volume 5 Issues 4 page 4627-4633. DOI: 10.18535/ijsshi/v5i4.12, ISSN: 2349-2031, 2018, THEIJSSHI.

Rukin. 2018. Economic development as a way to fight against poverty in a coastal society, Journal Masyarakat, Kebudayaan
\& Politik, Volume 31 Issues 2 page 230240. Universitas Airlangga, 2018.

Saraswati (2014) Peranan istri nelayan dalam menunjang kehidupan keluarga. Jurnal Fakultas Ilmu Sosial, Universitas Pendidikan Ganesha Singaraja.

Sara (2014) Pengelolaan Wilayah Pesisir. Gagasan Memelihara Aset Wilayah Pesisir dan Solusi Pembangunan Bangsa. Alfabeta Bandung.

Undang-undang Dasar Republik Indonesia Tahun 1945.

Undang-undang Nomor 6 Tahun 2014 tentang Desa. 